\title{
Senyk's Archive and its significance for studies on the behind-the-scenes picture of the Organisation of Ukrainian Nationalists. New research perspectives in the light of discovered correspondence ${ }^{1}$
}

Zarys treści: Zabójstwo ministra spraw wewnętrznych Bronisława Pierackiego w 1934 roku, jako najpoważniejsza akcja przeprowadzona przez Organizację Ukraińskich Nacjonalistów w latach międzywojennych, było pochodną napiętych relacji polsko-ukraińskich. Tzw. archiwum Senyka, znalezione przez wywiad czechosłowacki w 1933 roku i przekazane polskim władzom, zostało ujawnione zbyt późno, aby zapobiec tragedii, jednak stało się podstawą do sformułowania aktu oskarżenia przeciwko Stepanowi Banderze oraz innym członkom OUN zaangażowanym w terrorystyczną działalność wobec II Rzeczypospolitej. Archiwum składa się z około 700 listów wymienianych pomiędzy członkami Zarządu OUN na emigracji w pierwszej połowie lat 30. XX wieku. Autorka niniejszego artykułu odnalazła je w Centralnym Państwowych Archiwum Historycznym Ukrainy we Lwowie.

Content outline: The assassination of Bronisław Pieracki, Polish Minister of Interior, which took place in 1934, was the most significant operation carried out by the Organisation of Ukrainian Nationalists during the interwar period, and was a consequence of tense Polish-Ukrainian relations. The so-called Senyk's Archive, discovered by Czechoslovakian intelligence in 1933 and handed over to the Polish authorities, was disclosed too late to prevent the tragedy, yet it became grounds for the formulation of an indictment against Stepan Bandera and other OUN members involved in terrorist activities against the Second Polish Republic. The archive consists of about 700 letters exchanged by the members of the OUN Board in exile during the first half of the 1930s. The author of the present article discovered them in the Central State Historical Archive of Ukraine in Lviv.

1 The creation of the present article and conducting further research is possible owing to the financial support granted by the National Science Centre as part of the PRELUDIUM 15 programme, grant No. UMO-2018/29/N/HS3/01029, titled: "Behind the Scenes of the Functioning of the Organisation of Ukrainian Nationalists on Emigration in the Light of Correspondence (1929-1938)." The newly discovered documents will constitute the foundation for a doctoral dissertation of the same title. 
Słowa kluczowe: Archiwum Senyka, zabójstwo Bronisława Pierackiego, Organizacja Ukraińskich Nacjonalistów, II Rzeczpospolita, ukraińska emigracja

Keywords: Senyk's Archive, Bronisław Pieracki's murder, Organisation of Ukrainian Nationalists, Second Polish Republic, Ukrainian emigration

\section{Introduction}

As a result of the failed struggle for independence after the First World War, the areas inhabited by the Ukrainian population found themselves within the borders of four countries: the Soviet Union, the Second Polish Republic, Romania and Czechoslovakia. This resulted in the emergence of two paths of evolution of the Ukrainian nationalist movement: the legal one, based on the development of socio-cultural, economic and political life within the framework of the applicable law, and the illegal one, whose supporters opted for continued struggle for independence and the unification of lands considered Ukrainian by all available methods. The Ukrainian nationalist movement, which belongs to that second trend, had come a long way to eventually consolidate and establish, in 1929, the Organisation of Ukrainian Nationalists (OUN) with Yevhen Konovalets acting as its leader and moral authority. ${ }^{2}$ Although the aim of the organisation was to fight all the "occupiers" of Ukrainian lands, its activities were focused primarily on the Second Polish Republic. This was due to the particular international situation, to the nationalists' self-assessment of their chances and limitations, and to the fact that they considered Eastern Galicia the core of the future Ukrainian state. It was the area of operation of the domestic structures of the OUN, tasked with fulfilling the above objective. However, administration over the entire nationalist movement belonged to the expatriate activists located outside the lands considered natively Ukrainian, not only in terms of decision-making, but, above all, in the matters of morality, ideology and financing.

Until now, knowledge about the activities of the OUN was gathered primarily from propaganda materials, published programme announcements, as well as the organisation's official press and other internal documents. Some analyses and information obtained by the authorities of the countries of operation of the organisation were also available. One additional source of information were the numerous recollections of the members of the OUN after the Second World War, however, most often distorted and serving as a political weapon. Written correspondence, on the other hand, did not constitute essential research material, mainly because of its fragmentation, although this does not mean it was of no use either. ${ }^{3}$

2 For more information on the Organisation of Ukrainian Nationalists, see, inter alia, R. Wysocki, Organisation of Ukrainian Nationalists in Poland in 1929-1939, Lublin, 2003.

3 The OUN Archive in Kiev contains a rich collection of correspondence, also from the 1930s, which had partially been published, see for instance Ю. Черченко, “Листування Леоніда Мосендза 
The discovery of a collection of letters, the so-called Senyk's Archive, provides an incentive to launch new research and may not only constitute (together with other correspondence) a source base for the assessment of the Ukrainian nationalist movement, but also fill a gap in research on Polish-Ukrainian relations, especially in the context of the origin of events taking place during the Second World War. These documents also bring an important contribution to the question of the functioning of national minorities in Central and Eastern Europe and the emergence of nationalist ideologies in the 1920s and 1930s. The activity of Ukrainian émigrés was closely correlated with the developments in the international arena. Therefore, we should not underestimate the influence of the political situation in Europe and North America on the activity of the OUN, as well as their cooperation with individual countries, including Lithuania, Czechoslovakia and Germany, but also lobbying practices in Canada, Great Britain, France or Italy, i.e. wherever the émigré activists of the OUN Provid (Board) or its close collaborators were located.

Senyk's Archive belongs to a collection of documents which, due to its role in the trial regarding the murder of the Minister of Interior Bronisław Pieracki, as well as its mysterious route from Czechoslovakia to the Second Polish Republic, continues to incite both theories and the interest of researchers. The previously unavailable, yet expected content that could reveal the unknown behind-the-scenes activity of the OUN fuelled the curiosity of not only historians, but also of the direct participants or eyewitnesses of the 1930s and those events. Some scholars believe that all copies of Senyk's Archive were lost during the Second World War. This thesis, however, was refuted by Roman Wysocki, who provides information on this subject in his doctoral dissertation. ${ }^{4}$ The author of the present article has discovered an intact copy of the so-called Senyk's Archive at the Central State Historical Archive of Ukraine in Lviv (Центральний державний історичний архів України, Львів; hereinafter: CDIAUL). This raises the question of why no one had ever come across these materials before. According to Wysocki, who learned about the preservation of Senyk's Archive at the CDIAUL in the late 1990s: "in early 1998, when the collection was declassified, its confidentiality was extended indefinitely." Allegedly, this occurred on account of the efforts of the Ukrainian historian Yaroslav Dashkevych, who at that time was a member of the committee responsible for classified collections kept at the Lviv archive. ${ }^{6}$ These letters were added

з Михайлом Селешком (1938-1939рр.)," in: Пам'ятки. Археографічний щзорічник, vol. 9, 2008, pp. 3-23.

${ }^{4}$ R. Wysocki, Działalność Organizacji Ukrainskich Nacjonalistów w Polsce w latach 1929-1939 [doctoral dissertation], Lublin, 1999. The subsection "Senyk's Archive" is particularly interesting (pp. 360-365).

${ }^{5}$ Ibid., p. 364.

6 The author of the present article received information about Dashkevich's involvement in the concealment of documents from Professor Roman Wysocki. In October 1998, Wysocki did receive permission to order Senyk's Archive from the CDIAUL, but it was then revoked. 
to the inventory only a few years ago, and since then no researcher has queried through the OUN collection with enough detail to come across Senyk's Archive. In addition, these materials were placed by the employees of the archive in the fond (collection) of the Court of Appeal in Lviv among cases containing relatively low-value information related to staff of the institution. Because of its volume and thematic extent, this fond is yet to be fully discovered by the researchers.

The aim of the present article is not to examine the content of the archive, as the specific nature of the documentation contained therein requires appropriate preparation and extensive analysis. It is worth mentioning that the letters are often encrypted and deprived of their full context. The author's intention is to outline the context of Senyk's Archive, thus summarizing the current state of knowledge and, above all, indicating research perspectives.

\section{Assassination of Bronisław Pieracki and the behind-the-scenes of the acquisition of Senyk's Archive}

On 15 June 1934, the Polish Minister of Interior, Bronisław Pieracki, was murdered at ul. Foksal 3 in Warsaw. The murder, one of the most famous political assassinations of the Second Polish Republic, was carried out by Hryhorij Maciejko, a member of the OUN. ${ }^{7}$ This act was, at the same time, the most significant achievement of the Ukrainian nationalists during the interwar period (especially since the perpetrator was never captured; he remained in Argentina until his death in 1966) and their largest failure, resulting in a significant weakening of the domestic structures of the organisation. In the so-called Warsaw and Lviv trials (1935-1936), which aroused considerable public interest in Poland and abroad, several dozen people were charged, including the domestic OUN provid$n y k$ (leader) Stepan Bandera. ${ }^{8}$ Interestingly, the arrests of individuals suspected of belonging to the OUN-planned for a long time already-were carried out in Lviv only one day before the murder, on 14 June 1934. The operation was postponed at the urgent request of Minister Pieracki, who withheld the apprehensions on account of his meeting with Metropolitan Andrey Sheptytsky earlier that month, wishing to avoid provoking conflicts. ${ }^{9}$ The manhunt resulted notably in the exposure of the secret laboratory in Kraków where, as the investigation revealed, the bomb used during the attack on Pieracki was constructed (eventually it did not explode and the murderer used a revolver). The laboratory was discovered when

\footnotetext{
7 The author of the present article judged it pointless to describe the exact course of events here, as it can be found, for instance, in Władysław Żeleński’s book Zabójstwo Ministra Pierackiego, Warszawa, 1995.

${ }^{8}$ Interestingly, at the time of the arrest, the authorities had no idea about Bandera's role in the OUN. He was believed to be a regular member of the organisation.

9 W. Żeleński, Zabójstwo..., p. 22.
} 
the explosive charge was already in the hands of the perpetrator in Warsaw. The trial at the District Court in Warsaw began on 18 November 1935. 160 witnesses were summoned and the prosecutors were Kazimierz Rudnicki, ${ }^{10}$ public prosecutor at the Court of Appeal in Warsaw, and Władysław Żeleński, who compiled an extensive bill of indictment. ${ }^{11}$ The case files consisted allegedly of 25 volumes, 400 pages each (they have yet to be found). ${ }^{12}$ On 13 January 1936, the sentence was announced, the defendants receiving from seven years in prison to the death penalty, later commuted to life imprisonment following an amnesty. ${ }^{13}$

Contrary to widespread belief, Senyk's Archive proved to be rather accessory to the prosecution, as it contained very little information about the planned murder and most of the details had been discovered in the course of the investigation. However, if it had been known earlier (as it was probably obtained already in the autumn of 1933), the preparations for the murder could have been thwarted. The details contained therein did nonetheless contribute to bringing many facts together, filling in gaps, as well as providing an insight into the organisation's operation, funding, and ties with domestic structures. One of the biggest sensations was the evidence of cooperation between the OUN and Poland's neighbours, Czechoslovakia and Lithuania. The propaganda aspect is also important, influencing the morale within the structures of the OUN. These letters had cemented the division among the members of the organisation, which developed with full force during the Second World War. Some researchers believe (although there is no conclusive evidence for this) that the documents led to the death of leading OUN activists in 1941: Omelian Senyk himself, as well as Mykola Stsiborsky, a member of the Provid active in France in the 1930s; however, some believe in an interference by Soviet security services.

The discovery of Senyk's Archive was made possible by the cooperation of Polish and Czechoslovak military intelligence as early as in 1929, when a liaison office was established at the Czech Bureau II. ${ }^{14}$ In the autumn of 1933 and throughout 1934, this cooperation allowed the Czechoslovak police to search the houses and arrest the eight most important OUN activists living in Prague. The operation was based on evidence provided by Major Jerzy "Olaf” Krzymowski concerning collaboration between the OUN and the Abwehr. Major Josef Bartik, head of the

${ }^{10}$ Kazimierz Rudnicki wrote memoirs, but did not mention the murder of Pieracki; K. Rudnicki, Wspomnienia Prokuratora, Warszawa, 1956.

${ }_{11}$ Akt oskarżenia przeciwko Stefanowi Banderze, Mikołajowi Łebedowi, Darji Hnatkiwskiej, Jarosławowi Kapryńcowi, Bohdanowi Pidhajnemu, Iwanowi Malucy, Jakóbowi Czornijowi, Eugeniuszowi Kaczmarskiemu, Romanowi Myhalowi, Katarzynie Zaryckiej oraz Jarosławowi Rakowi, Warszawa, 1935.

12 M. Gawryszczak, Bronisław Wilhelm Pieracki (1895-1934). Biografia polityczna, Łódź, 2014, p. 81.

13 W. Żeleński, Zabójstwo..., p. 129.

14 The entire cooperation did not bring any significant results other than the discovery of the archive. The intensification that occurred was caused by Hitler's coming to power and the signing of the so-called Pact of Four, only to end very quickly afterwards. 
Czechoslovak counterintelligence office, was friendly towards Poles and responded positively to the request of his Polish colleagues. Most of the materials were found at the house of one of Yevhen Konovalets's closest associates, Omelian Senyk, and hence they were dubbed "Senyk's Archive." ${ }^{15}$ Major Bartik, without the knowledge of his superiors, and also in view of the difficulties caused by the materials being written entirely in Ukrainian, handed them over to Major Krzymowski. ${ }^{16}$ The latter, after brief examination, then sent the materials in parts to Warsaw asking that they be photographed, but also for discretion to be kept, since the Czechoslovak Ministries of Interior and Foreign Affairs had no idea about the operation, which was codenamed "Niebo" ("Heaven"). ${ }^{17}$ Two sets of photocopies were prepared at the headquarters of the Polish intelligence office and the originals were handed back to the Czechoslovak side, which planted them in the houses of the previously arrested members of the OUN. After a few weeks, the activists were released and they could see for themselves about the planned action. ${ }^{18}$

After a cursory review of the material, the members of the Second Department of Polish General Staff concluded that it was of little value to them, as they were only seeking information about ties with the Third Reich, and handed over the documents to the Ministry of the Interior. The materials were commissioned to be compiled and then transferred in typescript form to Teodor Wituński, investigating judge for matters of special significance chosen to conduct the investigation against the OUN members, who examined them in collaboration with a team of translators. This implies the existence of at least four copies of Senyk's Archive at that time; the originals could have been destroyed, while the two sets of photocopies prepared at the Polish Intelligence Office have still not been found. ${ }^{19}$ The author of the present article has now discovered the last version, prepared by the investigating judge. Therefore, it is not the complete archive received by the Polish authorities from the Czechoslovakian Intelligence Office (which is estimated to have comprised about 15,000 pages [sic! $\left.]^{20}\right)$, nor is it the entire collection

15 M. Jarnecki, Irredenta ukraińska w relacjach polsko-czechosłowackich latach 1918-1939, KaliszPoznań, 2009, pp. 178-179.

${ }^{16}$ However, it would be hard not to agree with Roman Wysocki's opinion that the argument about the difficulty caused by language was somehow exaggerated, R. Wysocki, Działalność Organizacji..., p. 361.

17 Między Warszawa o Praga. Polsko-czechosłowackie stosunki wojskowo-polityczne 1918-1939, ed. P. Kołakowski, Warszawa, 2007, p. 346.

18 The arrests resulted in significant dismay among the Ukrainian community, which blamed the Czechoslovak authorities. In turn, the Ministry of Foreign Affairs in Prague addressed an official question to the Ministry of the Interior and the Ministry of National Defence, to which the head of counterintelligence office promised to investigate the matter (sic!), claiming that they had nothing to do with the matter; ibid.

19 See: M. Jarnecki, Irredenta ukraińska $w$ relacjach polsko-czechosłowackich $w$ latach 1918-1939, Poznań, 2009.

20 The number of 15 thousand pages ( 30 volumes of about 500 sheets each) is mentioned by Feliks Swiątek, who was an employee of the Department of Nationalities of the Ministry of Interior 
found in the hands of Senyk and his associates and used in the trial (2,473 pages, i.e. 418 originals and 2,055 copies). ${ }^{21}$ As Judge Wituński explained, he only included materials that he considered valuable; in total about 1,450 pages. However, it can be assumed that most of the non-included documents (out of a total of 2,473 pages) would not be of any value to the contemporary researcher either. The fate of the archive outlined above was disclosed years later by the then head of Bureau II, Colonel Stefan Mayer, who revealed its existence in his correspondence to Władysław Żeleński. ${ }^{22}$

\section{What is Senyk's Archive?}

Senyk's Archive has been found by the author of the present article in fond (collection) 151 of the Court of Appeal in Lviv, series 1a, cases 5043a and 5043b. The letters next to the case numbers indicate that the documents were added to the collection later. Each case consists of a large binder containing all the documents. The first binder contains a separate small sheet of paper with the inscription: “Справи 5043a, 50436 в читальний зал не видавати до 2020 або навіть 2030" ("Cases 5043a and 5043b not to be released for reading until 2020 or even until 2030"). This note certainly dates back to the previous century, but as we know, the above recommendation has not been complied with. Pages (folios) 1 to 66 contain letters and a list of attachments drafted by civil servants. The first page already leaves little doubt that this is a copy of Senyk's Archive.

The contents of the first 66 folios deserve some explanation, as they disclose how these materials reached Lviv. By the letter of 5 February 1935, the Head of the Security Department at the Ministry of Interior, Stanisław Kucharski, delivered 1,512 "fragments of photographs, collected in 11 folders" to the investigative judge for matters of special significance, Teodor Wituński. ${ }^{23}$ Of these, 1,219 were

and was said to have had access to Senyk's Archive for some time. However, it is likely that it comprises all the documents collected by the Czechoslovak intelligence office over the past years. This raises the question of what were the contents of the remaining 13,000 pages, why they were not included in the case (even when limited to the most important documents), and whether they can still considered part of Senyk's Archive. All these questions require, however, further research.

21 Seе: П. Мірчук, Нарис історії Організації Українських Націоналістів: 1920-1939, МюнхенЛондон-Нью-Йорк, 1968.

22 These letters are currently kept at the Piłsudski Institute in London. The recollections of Colonel Mayer should nonetheless be approached with caution and compared with newly emerging information, especially from Czech archives. The entire case requires detailed explanation and the gathering of all available documents, although due to the secret nature of the operation, a large part of the information available at this stage of the research already appears contradictory.

${ }^{23}$ CDIAUL, f. 151, ser. 1a, case 5043a, Ministerstwo Spraw Wewnętrznych, Naczelnik Wydziału Bezpieczeństwa do Pana Sędziego Apelacyjnego Śledczego dla spraw wyjątkowego znaczenia Teodora Wituńskiego, No. PB 307/1, Warszawa, 5 II 1935, fol. 2. 
documents found at Omelian Senyk's house in the autumn of 1933, while 293 were recovered during a search in the houses of Roman Myrovych, Volodymyr Martynets, Dmytro Ravych, Ostap Chuchkevych, Volodymyr Zabavsky, Yaroslav Baranovsky and Evgen Kulchytsky in October $1934 .{ }^{24}$ According to information from 16 June 1935, Suchenek-Suchecki also sent 656 more photographs of documents revealed at Senyk's house. ${ }^{25}$ From folio 4 onwards we find a protocol of examination and a translation of the photographs into Polish (the translators were Walentyna Zawadzka, a clerk from Warsaw, and Jan Loho-Sobolewski, an assistant at the Faculty of Law of the Jan Kazimierz University in Lviv and at the same time a deputy commissioner of the State Police in Lviv). ${ }^{26}$ The translation was carried out from 15 February to 28 June 1935. According to the protocol, Wituński inspected only 24 photographs from the 656 sent in later. In 1936, the translated documents were extracted from the case file in Warsaw and sent to the Court of Appeal in Lviv, where another trial against the members of the OUN was opened. ${ }^{27}$

The entirety of the documents that have been recovered so far, bar court materials, consists of 718 attachments (mainly correspondence, several calculations and instructions) and separately: a report on a military course and a document concerning the OUN system. Each annex has been translated into Polish and rewritten on a typewriter. The translation is literal and contains the original errors and annotations. The pages 67 to 794 in the first binder and 1 to 716 in the second binder contain the attachments mentioned. The total number of pages is therefore 1,443 , as the number of pages was bound to change during the translation and rearrangement of the documents.

The archive consists mainly of letters, but also several other documents such as calculations, instructions and statutes. The most valuable, from today's point of view, is the correspondence exchanged not only between the key members of the OUN (members of the Provid), but also the letters they received from regular members. ${ }^{28}$ Many of the letters are partially or completely encrypted; each individual, strategic location or event had been assigned a different name (for instance, a "hornet" is a Polish police officer). One of the attachments is a dozen page-long explanation of some of the codes used, which significantly facilitates the work of researchers.

24 Ibid.

${ }^{25}$ CDIAUL, f. 151, ser. 1a, case 5043a, Ministerstwo Spraw Wewnętrznych do Pana T. Wituńskiego, Warszawa, 16 VI 1935, fol. 3.

${ }^{26}$ CDIAUL, f. 151, ser. 1a, case 5043a, Ministerstwo Spraw Wewnętrznych do Pana T. Wituńskiego, Warszawa, 16 VI 1935, fol. 4.

27 Ibid.

28 The remaining letters, some of which have been published, are scattered in various countries around the world (Ukraine, Czechia, Germany, Great Britain, Canada, the United States, perhaps Switzerland and Italy, i.e. everywhere where large concentrations of Ukrainian population could be found at that time). Some of the letters certainly remain in the private collections of the families of OUN members. 
It is worth noting that the OUN Provid in exile was not a gathering of random people. They were well-educated individuals, authors of books and press articles, with connections not only in legally operating Ukrainian émigré organisations, but also among the representatives of the countries in which they lived. They were acquainted with the situation both in the Second Polish Republic and in the international arena. They assessed their potential and conducted lobbying activities, and their evaluations may constitute an important addition to the research. Their letters contained references to operations carried out by domestic OUN activists; they were commented on and subjected to analysis. On the other hand, another factor that affects the perception of this correspondence and its use in research is the way it was written: often under the influence of emotions, on the spot; their authors expressed their first impressions, unprocessed over time, since they were addressed to trusted people. Most of the letters between Yevhen Konovalets and Omelian Senyk reveal how deep a relationship (also emotional) bound these two individuals, as well as reflect Senyk's influence on the OUN leader. All these aspects are important for the analysis proposed below, and the value of these letters, according to the author, exceeds that of the data collected from the press or propaganda materials. It offers insight into the internal structures of the OUN, detailing their weaknesses and strengths, as well as their dependencies and modus operandi.

\section{Overview of the current state of research: Polish and Ukrainian historiography}

The existence and content of Senyk's Archive remains one of the major mysteries in the history of Polish-Ukrainian relations. Many theories and myths have arisen around these documents. Since the end of the Second World War, both Polish and Ukrainian historians have been returning to the matter of Senyk's Archive and searching for its traces. The most probable option regarding its fate was that it has been shipped out to Russia or Germany during the war (or to another country inhabited by the Ukrainian diaspora). Speculations also appeared about the content of the archive itself. The research of Ukrainian émigré historians, Petro Mirchuk and Zinovy Knysh (both members of the OUN in the 1930s) yields two widely different results. The former stipulated in his flagship work Hapuc icmopii $\mathrm{OYH}$ that the archive must contain the most essential materials concerning the functioning of the OUN, including minutes of Provid meetings, lists of OUN agencies abroad and correspondence by its most important activists. ${ }^{29}$ Knysh on the other hand believed that the archive did not exist and had been fabricated by the Polish authorities for the purposes of the Warsaw trial. He assumed that the key

${ }^{29}$ П. Мірчук, op. cit. 
documents of the organisation must have been kept by Yevhen Konovalets in a different location. ${ }^{30}$ The theory about the documents being forged, although explained convincingly and in great detail by Knysh, was not supported by other researchers, and the preliminary analysis of the documents uncovered by the author of the present article, supported by source knowledge and numerous studies, leaves no doubt that the letters contained therein had not been forged. Interestingly, the dispute between the two researchers is reflected in an antagonism on ideological grounds. After the split within the OUN in 1940, Mirchuk belonged to the OUN-B faction (known as Banderites) and blamed Senyk for the arrest of Stepan Bandera, while Knysh joined his opponents, members of the OUN-M (known as Melnykites), who defended Senyk after the affair caused by the discovery of the documents, arguing, among other things, that these papers had been fabricated or at least that they were of negligible importance.

When studying the period of the Second Polish Republic-Polish-Ukrainian relations in particular-it is impossible not to be aware of the existence of Senyk's Archive, as well as its influence on the course of events. It is therefore impossible to list all the researchers who have addressed this issue in their works at least partly. Worth mentioning are the articles actually devoted to Senyk's Archive and summarising the state of the knowledge on this subject, especially the one written by the Ukrainian researcher Volodymyr Muravsky, and the earlier Polish one, by Feliks Swiątek. ${ }^{31}$ As the former rightly pointed out, the biggest challenge for the OUN after the discovery of these letters was not the very fact of their discovery, but their impact within the organisation. They largely contributed to the later split within the OUN, deepening the already existing differences between the "older" and "younger" camps. In the years 1939-1940, when the split took place, Senyk's Archive served as an important argument condemning the earlier activity of the PUN (Ukrainian Nationalist Provid) and resulted in the exclusion of Senyk from the Board. Muravsky believed that these materials had not survived to the present day, although he put forward the idea that they might still be stored in some archive in Warsaw. Świątek, in his article provocatively entitled "Was the so-called Senyk's Archive authentic, or was it an archive of forgeries?," argued that the documents were authentic, emphasizing their importance and hoping that at least one of the copies survived the Second World War. He also described what these

30 Seе: 3. Книш, Варшавський процес ОУН на підложжі польсько-украӥнських відносин тієї доби: У 2 томах, Торонто, 1986; 3. Книш, Архів Сеника. Історично-критична студія, Торонто-Нью-Йорк-Лондон-Сідней, 1992, рр. 153-166.

31 Seе: В. Муравський, “Документи Міністерства закордонних справ Чехословаччини про так званий „архів Сеника,” in: Український визвольний рух, ed. В. В’ятрович, Збірник 6, Львів, 2006, available at: http://shron1.chtyvo.org.ua/Muravskyi_Volodymyr/Dokumenty_Ministerstva_zakordonnykh_sprav_Chekhoslovachchyny_pro_tak_zvanyi_arkhiv_Senyka.pdf (accessed: 15 Dec 2018); F. Świątek, "Czy tzw. archiwum Senyka było autentyczne, czy też było to archiwum falsyfikatów?,” Najnowsze Dzieje Polski, 1914-1939, 9, 1965, pp. 275-280. 
materials looked like at the beginning: "Originally it was a loose file, or rather a pile of photographic papers with prints in negatives." 32 No doubts about the authenticity of Senyk's Archive were cast by Tadeusz Radzik either. In his review of Zinovy Knysh's book, he quoted, for instance, an internal report on the OUN prepared by the Ministry of Interior in 1936, which contained references to these documents-which would be pointless in the case of a forgery. ${ }^{33}$

Furthermore, in Poland, the murder of the Minister of Interior Bronisław Pieracki, as well as the interception of Senyk's Archive were reported in detail by a participant of those events, Władysław Żeleński, who served as auxiliary prosecutor on behalf of the public prosecutor's office during the Warsaw trial, ${ }^{34}$ and relied not only on his own memory as a direct participant in said events, but also on correspondence with people who could have provided him with any information. He established contact, among others, with one of the Ukrainians accused in the trial, Mykola Klymyshyn. He devoted his entire life to this case and concluded his personal investigation with a book. ${ }^{35}$

These documents were also frequently quoted in works of leading researchers in the field of Ukrainian nationalism ${ }^{36}$ and Polish-Ukrainian relations in general. ${ }^{37}$ The international dimension of the Ukrainian issue also incited interest. ${ }^{38}$ Michał Jarnecki was one of the scholars to attempt to reconstruct the behind-the-scenes of these events and determine how Senyk's Archive found its way into the hands of Poles based on intelligence reports. On the Ukrainian side, the interest is even

${ }^{32}$ F. Świątek, op. cit., p. 278.

33 T. Radzik, “Warszawskij procies OUN. Na popdłożenii polsko-ukraińskich widnosti tiej doby.' t. 1-2, Zinowij Knysz, Toronto 1986 [recenzja],” Rocznik Lubelski, 1991-1992, no. 33-34, pp. 137-141.

34 W. Żeleński, Zabójstwo ministra Pierackiego, Warszawa, 1995; id., “Zabójstwo ministra Pierackiego," Zeszyty Historyczne, 25, 1973, pp. 3-101; id., "Jeszcze o zabójstwie Pierackiego i rozrachunkach polsko-ukraińskich,” Zeszyty Historyczne, 46, 1978, pp. 126-183.

35 W. Żeleński, Zabójstwo ministra Pierackiego....

${ }^{36}$ L. Kulińska, Działalność terrorystyczna i sabotażowa nacjonalistycznych organizacji ukrainskich w Polsce 1922-1939, Kraków, 2009; R. Wysocki, Działalność Organizacji Ukraińskich Nacjonalistów w Polsce...; E. Prus, Herosi spod znaku tryzuba. Konowalec - Bandera - Szuchewycz, Warszawa, 1985; J. Radziejowski, "Kształtowanie się oblicza ideowego radykalnego nacjonalizmu ukraińskiego (1917-1929),” in: Polska, Polacy, mniejszości narodowe, ed. W. Wrzesiński, Wrocław, 1992; G. Rossoliński-Liebe, Bandera. Życie i mit ukraińskiego nacjonalisty. Faszyzm, ludobójstwo, kult, Warszawa, 2018; A. B. Szcześniak, W. Z. Szota, Droga do nikąd. Działalność Organizacji Ukraińskich Nacjonalistów i jej likwidacja w Polsce, Warszawa, 1973; O. Dumin, "Prawda o Ukraińskiej Organizacji Wojskowej", Zeszyty Historyczne, 30, 1974.

37 See: R. Torzecki, Kwestia ukraińska w Polityce III Rzeszy 1933-1945, Warszawa, 1972.

38 See: A. A. Zięba, Lobbing dla Ukrainy w Europie międzywojennej. Ukraińskie Biuro Prasowe w Londynie oraz jego konkurenci polityczni (do roku 1932), Kraków, 2010; id., Ukraińcy w Kanadzie wobec Polaków i Polski (1914-1939), Kraków, 1998; R. Wysocki, "Liga Narodów wobec pacyfikacji Galicji Wschodniej w 1930 roku a polsko-ukraińska konfrontacja na arenie międzynarodowej," in: Ukraincy w najnowszych dziejach Polski (1918-1939), vol. 1, ed. R. Drozd, Słupsk-Warszawa, 2000. 
stronger and applies to both expatriate and domestic Ukrainian researchers. ${ }^{39}$ While expressing the position of the OUN-b in his book L'Allemagne national-socialiste et l'Ukraine, Volodymyr Kosyk also did not doubt the authenticity of Senyk's Archive. ${ }^{40}$ The recollections of individuals working in the structures of the OUN merit a mention as a vast source of information. Volodymyr Martynets, editor of Rozbudova natsii and secretary of the PUN, mentioned that Senyk kept archival materials in various countries, while in Prague he only stored those of secondary importance and did not disclose their location to anybody. This is why none of the OUN members had retrieved the documents from Senyk's house when he was arrested in the street. Another important source are the memoirs of Yevhen Onatsky, ${ }^{41}$ who included the contents of many received letters in his diary from his stay in Italy, some of which are of significance for researchers. ${ }^{42}$ Also valuable are the testimonies of Mykola Klymyshyn, one of the defendants in the Warsaw trial, who explained his role in the murder of Pieracki in detail, claiming that it was marginal. ${ }^{43}$

The issue of Ukrainian nationalism was also an important research topic for Western historians, especially from the United States and Canada, but German researchers too devoted some attention to it, especially from the point of view of Ukrainian-German relations in the 1930s. ${ }^{44}$

39 See: Д. Андрієвський, “Міжнародна акця ОУН,” in: Організація Українських Націоналістів 1929-1954, [Париж], 1955; Євген Коновалецьь та його доба., Мюнхен, 1974; I. Łysiak-Rudnicki, Między historia a polityka, Wrocław, 2012; На вічну ганьбу Польщі, твердині варварства в Европі, Нью-Йорк, 1978; ОУН в світлі постанов Великих Зборів, конференцій та інших документів з боротьби 1929-1955, без місця, 1955; W. Poliszczuk, Dowody zbrodni OUN i UPA. Działalność ukraińskich struktur nacjonalistycznych w latach 1920-1999, Toronto, 2000; W. Poliszczuk, Nacjonalizm ukraiński w dokumentach, part 1-2, Toronto, 2002-2004; С. Шевчук, Пора сказати правду про наші Визвольні Змагання добитися волі для Галицької землі 1918-1939, Торонто, 1965; С. В. Віднянський, “Політика чехословацького уряду щодо укр. еміграції в міжвоєнний період,” in: Міжнародні зв'язки України: наукові пошуки і знахідки, Вип. 3., Київ, 1993; О. Зайцев, Український інтегральний націоналізм 1920-1930-х років: Нариси інтелектуальної історії, Київ, 2013; O. Zajcew, "Ukraińskie uniwersum symboliczne w Drugiej Rzeczypospolitej: inwazja integralnego nacjonalizmu," in: Metamorfozy społeczne. Kultura i społeczeństwo II Rzeczypospolitej, ed. W. Mędrzecki, A. Zawiszewska, Warszawa, 2012, рр. 67-84; Житомирська трагедія: пам'яти трагічної смерти О. Сеника-Грибівського ій М. Сціборського, Буенос-Айрес, 1949.

${ }^{40}$ W. Kosyk, L'Allemagne national-socialiste et l'Ukraine, Paris, 1986.

41 Seе: Є. Онацький, У вічному місті. Записки журналіста, vol. 1-4, Торонто, 1954, 1981, 1985, 1989.

${ }^{42}$ See: A. A. Zięba, Lobbing dla Ukrainy...; M. Wojnar, "The Struggle for Dominance in Eurasia: 'The International Politics of Ukrainian Nationalism' by Bohdan Kordiuk in the Context of Geopolitical Concepts of the Organisation of Ukrainian Nationalists during the 1930s," in: Studia z Dziejów Rosji i Europy Środkowo-Wschodniej, 52, 2017, no. 3, pp. 101-126.

43 Interestingly, he later initiated contact with Władysław Żeleński by letter, in which he explained his innocence and his position on those past years. These letters can also be found in Piłsudski's Archives in London.

44 See: J. A. Armstrong, Ukrainian Nationalism, New York, 1955; A. Motyl, The Turn to the Right: The Ideological Origins and Development of Ukrainian Nationalism, 1919-1929, New York, 1980; 


\section{Research perspectives}

The discovery of Senyk's Archive and gaining access to several hundred letters by leading OUN activists, which clarify many previously unknown facts, as well as the motives of nationalists, their organisational structure and undertaken actions, opens new research perspectives for researchers. The greatest value of this collection seems to consist in the insight into the internal relations between OUN members, as well as an opportunity to study the Ukrainian nationalist movement from the perspective of its members, who would detail their experiences on a regular basis. ${ }^{45}$

So far, no independent work about the activities of the OUN in exile has yet been published. Polish researchers were primarily interested in the functioning of the Organisation of Ukrainian Nationalists in Eastern Galicia. From the Polish point of view, the terrorist nature of the organisation's activities, aimed at the security of the Polish state, was emphasised. From the Ukrainian perspective, it was a heroic struggle for the independence of Ukraine, thus the means used to achieve this end were usually downplayed. Undertaking exhaustive research was hindered by the scattering of the remaining source materials and the impossibility of relying on a specific set of documents that would allow a reliable examination of the activities of the OUN over time. Moreover, the researchers usually focus on the period of the Second World War. The emergence of a large collection of letters such as Senyk's Archive provides new research perspectives and an opportunity to present the Organisation of Ukrainian Nationalists not only in the context of their activities, but also in the context of the events taking place in Europe at the time. Based on a preliminary analysis of the documents found, followed by a comparison with other letters available in the archives in Prague and Kiev, the author has chosen to define three basic groups of issues.

The first objective should be to illustrate the structure and mechanisms of functioning of the OUN in exile through the visualisation of their strategy and decisions, as well as an analysis of their effectiveness. The goal of the project is not to enumerate the actions, but to understand the methods of action and observe their consequences. This will be accomplished by analysing previously unknown correspondence, which, unlike other available sources, such as the press or propaganda materials, appears most likely to reflect the nationalists' actual plans, motivations and goals (especially in the case of an organisation operating in conspiracy). From

id., "Ukrainian Nationalist Political Violence in Interwar Poland, 1921-1939," East European Quarterly, 19, 1985, no. 1; F. Bruder, Den ukrainischen Staat erkämpfen oder sterben! Die Organisation ukrainischer Nationalisten (OUN) 1928-1948, Berlin, 2006; F. Golczewski, Deutsche und Ukrainer 1914-1939, Schöningh, 2010; F. Grelka, Die ukrainische Nationalbewegung unter deutscher Besatzungsherrschaft 1918 und 1941/42, Wiesbaden, 2005.

${ }^{45}$ It should be noted that the proposed analysis will be possible not only by virtue of access to Senyk's Archive, but will also compared with the remaining correspondence of key members of the Organisation of Ukrainian Nationalists in exile in years 1929-1938. 
this perspective, the letters must be analysed not just in search of facts, but most importantly of the reactions, opinions and emotions experienced by the authors of the letters, especially in the context of trust or treason. Such an approach is dictated by the very nature of correspondence as a research material.

Another objective is to present the relations between the domestic and emigrant structures of the OUN. The Organisation of Ukrainian Nationalists was composed of an expatriate board (concentrated mainly in Czechoslovakia, with representatives based in many countries of Western Europe, the United States and Canada) and a domestic board (based in Eastern Galicia). The expatriate activists, including Yevhen Konovalets, appointed themselves leaders of the entire Ukrainian nationalist movement and formally exercised control over the activities of domestic structures. However, relations between the two groups were strained from the very beginning, with disputes over their modus operandi, ideology, programme, extent of autonomy, and the ambitions of individual members. One of the lines of conflict was the dispute between the "older" members (experienced expatriate activists who had fought on the battlefronts of the First World War and beyond, and shaped the foundations of Ukrainian nationalism from the very beginning) and the "younger" ones (domestic OUN activists, located directly "on enemy ground," radical and often acting without a well thought-out strategy).

The very existence of the nationalist movement, especially in the case of Ukrainians who lacked the resources usually available when operating within one's own state, was based on developing networks of contacts. These networks were established between individuals, groups of people, organisations, companies or political parties. They relied on cooperation, but sometimes also led to conflicts and rivalry. The key task will therefore be to perform a quantitative and qualitative social network analysis of interpersonal, organisational and political contacts; of interdependencies both within and beyond the OUN. The established contacts were particularly important to the effectiveness of the OUN, as it relied on the capabilities of individuals, and the interdependencies were a measure of success or failure. Network analysis will allow to distinguish the most strongly cooperating subgroups, i.e. centres and peripheries, as well as to identify informal leaders, and the influence of individuals on the operation of the organisation or the flow of information. ${ }^{46}$ Above all, it will allow setting the activities of the Organisation of Ukrainian Nationalists in an international context by tracing their activities in other countries.

46 D. Batorski, M. Zdziarski, “Analiza sieciowa i jej zastosowanie w badaniach organizacji i zarządzania,” in: Problemy Zarządzania, 7, 2009, no. 4 (26), pp. 160-165. 


\section{Conclusion}

Senyk's Archive, as well as other correspondence of the members of the Organisation of Ukrainian Nationalists in exile, is invaluable to researchers studying PolishUkrainian relations. So far there exists no study, either in Polish or Ukrainian historiography, that would explore the activity of nationalists in exile in the first stage of their existence, i.e. from the establishment of the organisation in 1929 until the murder of Yevhen Konovalets in 1938. The discovery of Senyk's Archive, as well as the compilation of the remaining dispersed correspondence exchanged between the members of the OUN Provid provides an incentive to undertake such research. Letters require a detailed approach and meticulousness. Every information contained therein counts, as it reveals not only the general activity of the organisation, but also the everyday life of its members and the problems they encountered, as well as their attitude and motives. The general outline of the activity of the OUN is well known; the objective is not to present it in a classic form, as a timetable of individual events, but rather to unveil the mechanisms of action, the flow of information, the decisions as they were made, the genesis of the movement and of the attitudes, or the system of leader selection. An analysis of the established relations would be of key importance, as it will not only allow to reveal the behind the scenes of the functioning of the OUN, but also to set their existence in a wider international context.

\section{Abstract}

The assassination of Bronisław Pieracki, Polish Minister of Interior, which took place in 1934, was the most significant operation carried out by the Organisation of Ukrainian Nationalists during the interwar period, and was a consequence of tense Polish-Ukrainian relations. The so-called Senyk's Archive, discovered by Czechoslovakian intelligence in 1933 and handed over to the Polish authorities, was disclosed too late to prevent the tragedy, yet it became grounds for the formulation of an indictment against Stepan Bandera and other OUN members involved in terrorist activities against the Second Polish Republic. The archive consists of about 700 letters exchanged by the members of the OUN Board in exile. The author of the present article has discovered them in the Central State Historical Archive of Ukraine in Lviv. The discovery of these documents raises new research problems, and also allows us to answer questions that have remained a mystery until now. The analysis of the letters will allow to fill the gaps not only in our knowledge of the functioning of the OUN, but also in the Polish-Ukrainian relations of the interwar period. It will also constitute an important contribution to the understanding of the emergence of nationalism throughout Europe in the 1930s. The international context is also very important. The letters of OUN members provide the researchers with insight not only into the internal modus operandi of the group, but also into their lobbying efforts, conducted all over the world. The OUN sought to establish cooperation with Poland's neighbours (Germany, Czechoslovakia, Lithuania), as well as Western European powers (e.g. Great Britain, Italy), Canada and the United States, i.e. wherever the Ukrainian diaspora was active. The author's intention is to outline the context of Senyk's Archive, thus summarising the current state of knowledge and, above all, indicating research perspectives. 


\section{Bibliography:}

\section{Archival materials}

Центральний державний історичний архів України, Львів (CDIAUL), f. 151, ser. 1 .

\section{Compilations}

Akt oskarżenia przeciwko Stefanowi Banderze, Mikołajowi Łebedowi, Darji Hnatkiwskiej, Jarosławowi Kapryńcowi, Bohdanowi Pidhajnemu, Iwanowi Malucy, Jakóbowi Czornijowi, Eugeniuszowi Kaczmarskiemu, Romanowi Myhalowi, Katarzynie Zaryckiej oraz Jarosławowi Rakowi, Warszawa, 1935.

Андрієвський, “Міжнародна акця ОУН,” in: Організація Українських Націоналістів 1929-1954, [Париж], 1955.

Armstrong J.A., Ukrainian Nationalism, New York, 1955.

Batorski D., Zdziarski M., "Analiza sieciowa i jej zastosowanie w badaniach organizacji i zarządzania," in: Problemy zarzadzania 2009, no. 4 (26), pp. 157-184.

Bruder F., Den ukrainischen Staat erkämpfen oder sterben! Die Organisation ukrainischer Nationalisten (OUN) 1928-1948, Berlin, 2006.

Черченко Ю., “Листування Леоніда Мосендза з Михайлом Селешком (1938-1939рр.)," Пам'ятки. Археограбічний щорічник, 9, 2008, pp. 3-23.

Gawryszczak M., Bronisław Wilhelm Pieracki (1895-1934). Biografia polityczna, Łódź, 2014.

Jarnecki M., Irredenta ukraińska w relacjach polsko-czechosłowackich $w$ latach 1918-1939, Poznań, 2009.

Євген Коновалеиьь та його доба, Мюнхен, 1974.

Книш 3., Архів Сеника. Історично-критична студія, Торонто-Нью-Йорк-Лондон-Сідней, 1992.

Книш 3., Варшавський процес ОУН на підложжі польсько-украйнських відносин тієї доби: У 2 томах, Торонто, 1986.

Kosyk W., L'Allemagne national-socialiste et l'Ukraine, Paris, 1986.

Kosyk W., The Third Reich and the Ukrainian Question. Documents 1934-1944, London, 1991.

Kozaczuk W., Bitwa o tajemnice. Stużby wywiadowcze Polski i Niemiec 1918-1939, Warszawa, 1999.

Kulińska L., Działalność terrorystyczna i sabotażowa nacjonalistycznych organizacji ukraińskich w Polsce 1922-1939, Kraków, 2009.

Łysiak-Rudnicki I., Między historia a polityką, Wrocław, 2012.

Między Warszawa a Pragą. Polsko-czechosłowackie stosunki wojskowo-polityczne 1918-1939, ed. P. Kołakowski, Warszawa, 2007.

Мірчук П., Нарис історії Організації Українських Націоналістів: 1920-1939, МюнхенЛондон-Нью-Йорк, 1968.

Motyl A., The Turn to the Right: The Ideological Origins and Development of Ukrainian Nationalism, 1919-1929, New York, 1980.

Motyl A., "Ukrainian Nationalist Political Violence in Interwar Poland, 1921-1939," in: East European Quarterly 1985, v. 19, no. 1.

Муравський, “Документи Міністерства закордонних справ Чехословаччини про так званий 'архів Сеника,' in: Український визвольний рух, ed. В. В’ятрович, Збірник 6, Львів, 2006.

На вічну ганьбу Польщі, твердині варварства в Европі, Нью-Йорк, 1978.

Онацький Є., У вічному місті. Записки журналіста, vol. 1-4, Торонто, 1954, 1981, 1985, 1989. 
ОУН в світлі постанов Великих Зборів, конференцій та інших документів з боротьби 1929-1955, без місця, 1955.

Papierzyńska-Turek M., "Praca organiczna czy walka? Ukraińska myśl polityczna w II Rzeczypospolitej wobec problemu niepodległości," in: Polska Akademia Umiejętności, vol. 2, Prace Komisji Wschodnioeuropejskiej, Kraków, 1995.

Piotrowski T., Ukrainian Integral Nationalism. Chronological Assessment and Bibliography, Toronto, 1997.

Poliszczuk W., Dowody zbrodni OUN i UPA. Działalność ukraińskich struktur nacjonalistycznych w latach 1920-1999, Toronto, 2000.

Poliszczuk W., Nacjonalizm ukrainski w dokumentach, part 1-2, Toronto, 2002-2004.

Prus E., Herosi spod znaku tryzuba. Konowalec - Bandera - Szuchewycz, Warszawa, 1985.

Radziejowski J., "Kształtowanie się oblicza ideowego radykalnego nacjonalizmu ukraińskiego (1917-1929)," in: Polska, Polacy, mniejszości narodowe, ed. W. Wrzesiński, Wrocław, 1992.

Radzik T., “Warszawskij procies OUN. Na pidłożenii polsko-ukraińskich widnosti tiej doby', t. 1-2, Zinowij Knysz, Toronto 1986 [recenzja]," Rocznik Lubelski 1991-1992, no. 33-34, pp. 137-141.

Rossoliński-Liebe G., Bandera. Życie i mit ukraińskiego nacjonalisty. Faszyzm, ludobójstwo, kult, Warszawa, 2018.

Stryjek T., "Dmytro Doncow a problem stosunków polsko-ukraińskich," Warszawskie Zeszyty Ukrainoznawcze 1998, vol. 8.

Szcześniak A. B., Szota W. Z., Droga do nikąd. Działalność Organizacji Ukraińskich Nacjonalistów i jej likwidacja w Polsce, Warszawa, 1973.

Шевчук С. Пора сказати правду про наші Визвольні Змагання добитися волі для Галииьької землі 1918-1939, Торонто, 1965.

Szota W., "Zarys rozwoju Organizacji Ukraińskich Nacjonalistów i Ukraińskiej Armii Powstańczej”, Wojskowy Przegląd Historyczny 1963, y. 8, no. 1.

Świątek F., "Czy tzw. archiwum Senyka było autentyczne, czy też było to archiwum falsyfikatów?"” Najnowsze Dzieje Polski, 1914-1939, 9, 1965, pp. 275-280.

Tomaszewski J., "Kwestia ukraińska w Polsce międzywojennej w czechosłowackich raportach dyplomatycznych," Warszawskie Zeszyty Ukrainoznawcze, 3, 1996.

Torzecki R., Kwestia ukraińska w Polityce III Rzeszy 1933-1945, Warszawa, 1972.

Віднянський С. В., "Політика чехословацького уряду щодо укр. еміграції в міжвоєнний період”, in: Міжнародні зв'язки України: наукові пошуки і знахідки, Вип. 3., Київ, 1993.

Wojnar M., "The Struggle for Dominance in Eurasia: 'The International Politics of Ukrainian Nationalism' by Bohdan Kordiuk in the Context of Geopolitical Concepts of the Organisation of Ukrainian Nationalists during the 1930s," Studia z Dziejów Rosji i Europy Środkowo-Wschodniej, 52, 2017, no. 3, pp. 101-126.

Wysocki R., Działalność Organizacji Ukraińskich Nacjonalistów w Polsce w latach 1929-1939 [doctoral dissertation], Lublin, 1999.

Wysocki R., "Liga Narodów wobec pacyfikacji Galicji Wschodniej w 1930 roku a polsko-ukraińska konfrontacja na arenie międzynarodowej," in: Ukraincy w najnowszych dziejach Polski (1918-1939), vol. 1, ed. R. Drozd, Słupsk-Warszawa, 2000.

Wysocki R., Organizacja Ukraińskich Nacjonalistów w Polsce w latach 1929-1939, Lublin, 2003. Зайцев О., Український інтегральний націоналізм 1920-1930-х років: Нариси інтелектуальної історії, Київ, 2013.

Zajcew O., "Ukraińskie uniwersum symboliczne w Drugiej Rzeczypospolitej: inwazja integralnego nacjonalizmu," in: Metamorfozy społeczne. Kultura i społeczeństwo II Rzeczypospolitej, ed. W. Mędrzecki, A. Zawiszewska, Warszawa, 2012, pp. 67-84.

Zięba A. A., Lobbing dla Ukrainy w Europie międzywojennej. Ukrainskie Biuro Prasowe w Londynie oraz jego konkurenci polityczni (do roku 1932), Kraków, 2010. 
Zięba A. A., Ukraińcy w Kanadzie wobec Polaków i Polski (1914-1939), Kraków, 1998.

Żeleński W., “Jeszcze o zabójstwie Pierackiego i rozrachunkach polsko-ukraińskich," Zeszyty Historyczne, 46, 1978, pp. 126-183.

Żeleński W., “Zabójstwo ministra Pierackiego," Zeszyty Historyczne, 25, 1973, pp. 3-101.

Żeleński W., Zabójstwo ministra Pierackiego, Warszawa, 1995.

Житомирська трагедія: пам'яти трагічної смерти О. Сеника-Грибівського ій М. Сціборського, Буенос-Айрес, 1949.

Magdalena Gibiec, PhD student at the Institute of History of the University of Wrocław (magdalena.gibiec@uwr.edu.pl)

Submitted 4.04.2019; accepted 12.06.2019 